\title{
FAKTOR RISIKO PENYEBAB TERJADINYA STUNTING PADA BALITA UMUR 12-59 BULAN DI KELURAHAN KAMPUNG BARU KEC. LUBUK BEGALUNG TAHUN 2015
}

\author{
Risk Factors Cause the Stunting of Age 12-59 Months in Kampung Baru \\ Kec. Lubuk Begalung in 2015
}

\author{
Erni Maywita \\ Dosen Tetap Fakultas Kesehatan Masyarakat - Universitas Baiturrahmah, Padang \\ Email : ernimaywita10@gmail.com
}

\begin{abstract}
Abstrak
Prevalensi stunting pada balita di Indonesia masih tinggi terutama pada usia 12-59 bulan. Tujuan penelitian untuk mengetahui faktor risiko penyebab terjadinya stunting pada balita yang berumur 12-59 bulan di Kelurahan Kampung Baru Kecamatan Lubuk Begalung PadangJenis penelitian observasional dengan rancangan casecontrol study. Penentuan sampel Studi kasus kontrol berpasangan dengan rasio 1:1 dengan jumlah sampel 29:29. Uji statistik univariat menggunakan distribusi frekuensi, bivariat menggunakan chi-square dan multivariat. Hasil penelitian Balita yang tidak diberikan ASI secara Ekslusif $32.0 \%$ menderita stunting. Balita yang mendapatkan pola asuh yang kurang baik $66.7 \%$ menderita stunting. Balita yang pendapatan keluarganya yang kurang baik $42.1 \%$ menderita stunting. Tingkat pendidikan ibu yang rendah $37.5 \%$ balitanya menderita stunting. Balita yang memiliki jumlah keluarga yang lebih dari lima orang 52,4\% menderita stunting. Balita yang memiliki riwayat penyakit infeksi $62.9 \%$ menderita stunting. Balita yang pernah menderita ISPA saja dalam 6 bulan terkhir 66.7 $\%$ menderita stunting. Balita yang tidak memanfaatkan pelayanan posyandu $60.9 \%$ menderita stunting. Ada hubungan yang bermakna antara pemberian ASI $(\mathrm{OR}=0,269)$, pola asuh gizi $(\mathrm{OR}=3.63)$, riwayat penyakit infeksi (OR 3.868) dengan Kejadian Stunting. Tidak ada hubungan yang bermakna antara pendapatan keluarga, tingkat pendidikan ibu, jumlah keluarga, pemanfaatan pelayanan posyandu dengan Kejadian Stunting. Faktor dominan penyebab terjadinya stunting adalah pola asuh gizi. Perlu adanya peningkatan penyuluhan mengenai gizi kepada ibu balita oleh petugas kesehatan sehingga meningkatnya kesadaran ibu untuk memperbaiki status gizi anak yang menyangkut tentang bagaimana memberikan pola asuh yang baik, dapat mendeteksi lebih dini kejadian stunting pada balitanya.
\end{abstract}

Kata kunci : Stunting, pemberian ASI, pola asuh, tingkat pendidikan, riwayat penyakit infeksi, pemanfaatan pelayanan kesehatan

\begin{abstract}
The prevalence of stunting in toddlers in Indonesia is still high, especially at the age 12 to 59 months. The aim of this research is to know the risk factor causes stunting to the toddlers who have the age 12 to 59 months in Kelurahan Kampung Baru Sub district of Lubuk Begalung Padang. The type of this research is observational with draft of case-control study. The dependent variable is the incidence of stunting in toddlers at the age 12 to 59 months. The sampling of case-control study is paired by ratio 1:1 with the number of samples 29:29. Univariate statistical test is using the distribution of frequency and also bivariate is using chi-square and multivariate. The result of this study is the toddlers who are not exclusively for getting ASI as much as 32\% suffer from stunting. The toddlers who get poor parenting are $66.7 \%$ suffer from stunting, the toddlers who have families' income are less well as much as $42.1 \%$ suffer from stunting, low mothers' education level are $37.5 \%$ causes their toddlers suffer from stunting, the toddlers who have quantity of families more than 5 person are $52.4 \%$ suffer from stunting, the toddlers who have a history of infectious diseases are $62.9 \%$ suffer from stunting, the toddlers who suffer from ISPA in the last six months are $66.7 \%$ suffer from stunting, the toddlers who do not utilize Posyandu service are $60.9 \%$ suffer from stunting. There was a significant association of giving ASI $(\mathrm{OR}=0,269)$, nutrition parenting $(\mathrm{OR}=3.63 \%)$, a history of infectious diseases ( $\mathrm{OR} 3.868)$ from stunting occurrence. There is no significant relationship between families' income, mothers' education level, quantity of families, Posyandu service utilization with the event of stunting. The dominant factor cause of stunting is parenting nutrition.It is important to increase education about nutrition to mothers by health workers so that awareness of mothers to improve the nutritional of toddlers is concerned about how to provide good parenting that can detect early occurrence of stunting in toddlers.
\end{abstract}

Keywords: Stunting, giving breastfeeding, parenting, level of education, a history of infectious diseases, utilization of health service. 


\section{PENDAHULUAN}

Stunting merupakan kondisi kronis yang menggambarkan terhambatnya

pertumbuhan karena malnutrisi jangka panjang. Stunting menurut WHO Child Growth Standart didasarkan pada indeks panjang badan dibanding umur $(\mathrm{PB} / \mathrm{U})$ atau tinggi badan dibanding umur $(\mathrm{TB} / \mathrm{U})$ dengan batas (z-score) kurang dari -2 SD (Eastwood, 2003).

Stunting yang terjadi pada masa anak merupakan faktor risiko meningkatnya angka kematian, kemampuan kognitif dan perkembangan motorik yang rendah serta fungsi tubuh yang tidak seimbang, perkembangan motorik yang rendah serta fungsi-fungsi tubuh yang tidak seimbang (Allen, 2002). Stunting pada balita perlu menjadi perhatian khusus karena dapat menghambat perkembangan fisik dan mental anak. Stunting berkaitan dengan peningkatan risiko kesakitan dan kematian serta terhambatnya pertumbuhan kemampuan motorik dan mental (Kemenkes RI, 2010). Stunting juga meningkatkan risiko obesitas, karena orang dengan tubuh pendek berat badan idealnya juga rendah. Kenaikan berat badan beberapa kilogram saja bisa menjadikan Indeks Masa Tubuh (IMT) orang tersebut naik melebihi batas normal. Keadaan overweight dan obesitas yang terus berlangsung lama akan meningkatan risiko kejadian penyakit degeneratife (Astari, 2005).

Prevalensi pendek (stunting) menurut provinsi dan nasional. Prevalensi pendek secara nasional tahun 2013 adalah 37,2 persen, yang berarti terjadi peningkatan dibandingkan tahun $2010(35,6 \%)$ dan 2007 (36,8\%). Prevalensi pendek sebesar 37,2 persen terdiri dari 18,0 persen sangat pendek dan 19,2 persen pendek. Pada tahun 2013 prevalensi sangat pendek menunjukkan penurunan, dari 18,8 persen tahun 2007 dan 18,5 persen tahun 2010. Prevalensi pendek meningkat dari 18,0 persen pada tahun 2007 menjadi 19,2 persen pada tahun 2013 (Riskesdas 2013). Data Profil Kesehatan Sumatera Barat pada tahun 2012 prevalensi gizi kurang di Kota Padang sebesar $10.68 \%$, dimana Puskesmas Lubuk Begalung merupakan 10 Puskesmas yang prevalensi Gizi kurang di atas prevalensi provinsi yaitu sebesar $10,73 \%$.

Berdasarkan latar belakang diatas penulis tertarik untuk melakukan penelitian mengenai faktor risiko penyebab stunting pada balita yang berumur 6-59 bulan di Kelurahan
Kampung Baru Wilayah Kerja Puskesmas Lubuk Begalung Padang.

\section{METODE PENELITIAN}

Penelitian dengan metode observasional dengan rancangan case-control study yang dilakukan di Kelurahan Kampung Baru. Populasi dalam penelitian ini adalah seluruh balita yang berumur 12-59 bulan di kelurahan Kampung Baru dengan jumlah balita 300 orang balita. Penentuan sampel Studi kasus control berpasangan dengan rasio 1:1dengan perhitungan sebagai berikut:

$$
n_{1}=n_{2}=\llbracket \frac{\frac{z_{\alpha}}{2}+z_{\beta} \sqrt{P Q}}{\left(P-\frac{1}{2}\right)} \rrbracket^{2}
$$

Diketahui:

$$
\begin{aligned}
& z \alpha=0.05=1.96 \\
& z \beta=0.10=1,282 \\
& N=300 \\
& \text { Kasus }=65 \text { orang } \\
& P=65 / 300=0.216(21.6 \%) \\
& Q=1-0,22=0.78
\end{aligned}
$$

$n_{1}=n_{2}=\llbracket \frac{\frac{z_{\alpha}}{2}+z_{\beta} \sqrt{P Q}}{\left(P-\frac{1}{2}\right)} \rrbracket^{2}$

$n_{1}=n_{2}=\llbracket \frac{\frac{1.96}{2}+1,282 \sqrt{0.22 \times 0.78}}{\left(0.22-\frac{1}{2}\right)} \|^{2}$

$n_{1}=n_{2}=\llbracket \frac{0.98+1.282 \sqrt{0,1716}}{(-0,28)} \rrbracket^{2}$

$n_{1}=n_{2}=\llbracket \frac{0.98+0.53}{(-0,28)} \rrbracket^{2}$

$n_{1}=n_{2}=\llbracket 5.39 \rrbracket^{2}$

$n_{1}=n_{2}=29.08$

$n_{1}=n_{2}=29$

Jadi sampel yang diperlukan adalah 29:29 dengan total sampel 58 orang Analisis data meliputi analisis univariat, bivariat dan multivariat.

\section{HASIL PENELITIAN}

Penelitian ini dilakukan terhadap 58 sampel yang terdiri dari sampel kasus dan control yangmemenuhi kriteria inklusi sebagai 
subjek penelitian. Data yang diperoleh dikelompokkan dan ditabulasikan sesuai dengan karakteristik masing-masing didapatkan hasil sebagai berikut:

Pada Tabel 1 terlihat bahwa faktor risiko yang diteliti ditemukan jumlah persentasi yang cukup besar terjadinya stunting pada balita yaitu pada faktor risiko pemanfaatan pelayan posyandu, dimana ibu balita tidak memanfaatkan pelayanan posyandu sebesar $60,3 \%$.

Sebaliknya ditemukan jumlah persentasi yang kurang dari separuh pada faktor risiko, seperti pemberian ASI, dimana $43.1 \%$ ibu yang tidak memberikan ASI secara eksklusif. Pola asuh ibu yang kurang baik (46.6\%). Pendapatan keluarga yang kurang baik $(32.8 \%)$. Tingkat pendidikan ibu rendah $(13.8 \%)$. Besar keluarga $>5$ orang $(39.7 \%)$. Balita yang memiliki riwayat penyakit infeksi39.7\%.

Tabel 1. Distribusi Faktor Risiko Stunting pada Balita Usia 12-59 bulan di kelurahan Kampung Baru Kecamatan Lubuk Begalung Padang tahun 2015

\begin{tabular}{|c|c|c|c|}
\hline \multicolumn{2}{|c|}{ Variabel } & \multirow{2}{*}{$\frac{\mathbf{n}}{25}$} & \multirow{2}{*}{$\begin{array}{c}\% \\
43.1\end{array}$} \\
\hline Pemberian & Tidak & & \\
\hline ASI & Eksklusif & 33 & 56.9 \\
\hline \multirow{2}{*}{ Pola Asuh } & Kurang Baik & 27 & 46.6 \\
\hline & Baik & 31 & 53.4 \\
\hline Pendapatan & Kurang Baik & 19 & 32.8 \\
\hline Keluarga & Baik & 39 & 67.2 \\
\hline Tingkat & Rendah & 8 & 13.8 \\
\hline Pendidikan & Tinggi & 50 & 86.2 \\
\hline \multirow{2}{*}{$\begin{array}{l}\text { Jumlah } \\
\text { keluarga }\end{array}$} & $\geq 5$ orang & 23 & 39.7 \\
\hline & $<5$ orang & 35 & 60.3 \\
\hline \multirow{2}{*}{$\begin{array}{l}\text { Pemanfaatan } \\
\text { Pelayanan } \\
\text { Posyandu }\end{array}$} & $\begin{array}{l}\text { Tidak } \\
\text { dimanfaatkan }\end{array}$ & 35 & 60.3 \\
\hline & Dimanfaatkan & 23 & 39.7 \\
\hline \multirow{3}{*}{$\begin{array}{l}\text { Riwayat } \\
\text { Penyakit } \\
\text { Infeksi }\end{array}$} & Ada & 23 & 39.7 \\
\hline & & & \\
\hline & Tidak ada & 35 & 60.3 \\
\hline
\end{tabular}

Berdasarkan hasil analisis bivariat pada tabel 2 dengan uji chi-square yang dilakukan pada faktor risiko yang diteliti, didapatkan hubungan yang signifikan pada variabel antara pemberian ASI $(\mathrm{OR}=0,269)$, pola asuh gizi $(\mathrm{OR}$ $=3.63$ ), riwayat penyakit infeksi (OR 3.868) dengan Kejadian Stunting.Tidak ada hubungan yang bermakna antara pendapatan keluarga, tingkat pendidikan ibu, jumlah keluarga, pemanfaatan pelayanan posyandu dengan kejadian Stunting.

Tabel 2. Analisis Bivariat Faktor Risiko (Pemberian ASI, Pola Asuh, Pendapatan Keluarga, Tingkat Pendidikan Ibu, Besar Keluarga, Pemanfaatan Pelayanan Kesehatan, Kejadian Penyakit Infeksi) pada Balita Usia 12-59 bulan di kelurahan Kampung Baru Kecamatan Lubuk Begalung Padang tahun 2015

\begin{tabular}{|c|c|c|c|c|c|c|c|c|}
\hline \multicolumn{2}{|c|}{ Variabel } & \multicolumn{2}{|c|}{ Stunting } & \multicolumn{2}{|c|}{ Normal } & & & \multirow[t]{2}{*}{$\mathrm{p}$} \\
\hline & & $\bar{f}$ & $\%$ & $\mathrm{f}$ & $\%$ & $\mathrm{n}$ & $\%$ & \\
\hline \multirow[t]{2}{*}{ Pemberian ASI } & Tidak Ekslusif & 6 & 27.6 & 17 & 58.6 & 25 & 43.1 & \multirow{2}{*}{0.034} \\
\hline & Ekslusif & 21 & 72.4 & 12 & 41.4 & 33 & 56.9 & \\
\hline \multirow[t]{2}{*}{ Pola Asuh } & Kurang Baik & 18 & 62.1 & 9 & 31.0 & 27 & 46.6 & \multirow{2}{*}{0.034} \\
\hline & Baik & 11 & 37.9 & 20 & 69.0 & 31 & 53.4 & \\
\hline Pendapatan & KurangBaik & 8 & 27.6 & 11 & 37.9 & 19 & 32.8 & \multirow{2}{*}{0.576} \\
\hline Keluarga & Baik & 21 & 72.4 & 18 & 62.1 & 39 & 67.2 & \\
\hline Tingk & Rendah & 3 & 10.3 & 5 & 17.2 & 8 & 13.8 & \multirow{2}{*}{0.70} \\
\hline pendidikan & Tingg & 26 & 89.7 & 24 & 82.8 & 50 & 86.2 & \\
\hline Anggota & $\geq 50$ & 11 & 37.9 & 10 & 34.5 & 21 & 36.2 & \multirow{2}{*}{0.1} \\
\hline keluarga & $<5$ orang & 18 & 62.1 & 19 & 65.5 & 37 & 63.8 & \\
\hline \multirow{2}{*}{ Penyakit infeksi } & Ada & 22 & 75.9 & 13 & 44.8 & 35 & 60.3 & \multirow{2}{*}{0.032} \\
\hline & Tidak ada & 7 & 24.1 & 16 & 55.2 & 23 & 39.7 & \\
\hline Pelayanan & Tidak & 14 & 48.3 & 9 & 31.0 & 23 & 39.7 & 0.28 \\
\hline Posyandu & Dimanfaatkan & 15 & 51.7 & 20 & 69.0 & 35 & 60.3 & \\
\hline
\end{tabular}

Analisis multivariat dilakukan untuk melihat pengaruh antara beberapa variabel independen dengan variabel dependen. Variabel yang akan dianalisis adalah variabel yang memiliki nilai $\mathrm{p}<0,25$ pada analisis bivariate chi-square. Terdapat enam variabel yang memenuhi kriteria analisis multivariat, dependen yang diduga berhubungan dengan stunting pada balita (12-59 bulan) yaitu variable pemberian ASI Eklusif, pola asuh gizi, pendapatan keluarga, pendidikan ibu, jumlah keluarga, penyakit infeksi, pelayanan kesehatan posyandu. Sebelum semua variable dapat dimasukan kedalam permodelan multivariate dilakukan seleksi kandidat dengan hasil $\mathrm{p}$ value $<0.25$ dan mempunyai kemaknaan secara substansi.

Hasil analisis bivariate antara variabel independen dengan variable dependen diketahui bahwa ada 4 variabel yang nilai $p$ value $<0.25$ yaitu varibel pemberian ASI, pola asuh gizi, riwayat penyakit infeksi, pelayanan kesehatan posyandu. Variabel dengan nilai $p$ value > 0.25 tidak dapat diikutkan dalam seleksi permodelan multivariat.

Hasil analisis bivariat antara variabel dependen dengan variabel dependen untuk seleksi peermodelan multivariat dapat dilihat pada tabel berikut: 
Tabel 3. Hasil Analisis Bivariat antara Variable Independen dengan Varaibel Dependen untuk Seleksi Permodelan Multivariat

\begin{tabular}{|c|c|c|c|}
\hline No & Variabel & $P$ value & $\begin{array}{l}\text { OR }(95 \\
\% \text { CI })\end{array}$ \\
\hline 1 & Pemberian ASI & 0.016 & 0,269 \\
\hline 2 & Pola asuh gizi & 0.017 & 3.636 \\
\hline 3 & $\begin{array}{l}\text { Riwayat Penyakit } \\
\text { Infeksi }\end{array}$ & 0.015 & 3.868 \\
\hline 4 & $\begin{array}{l}\text { Pemanfaatan } \\
\text { Pelayanan Posyandu }\end{array}$ & 0.178 & 2.074 \\
\hline
\end{tabular}

Langkah selanjutnya variable yang masuk kedalam kandidat dilakukan uji regresi logistik ganda. Variabel yang dianggap penting masuk kedalam model akan dipertahankan jika $\mathrm{p}$ value nya $<0.25$, sedangkan variabel yang memiliki $\mathrm{p}$ value $>0.25$ dikeluarkan. Pengeluaran variable dari model dilakukan bertahap mulai dari variable yang memiliki $p$ value $<0.25$ dan bermakna secara substansi ke dalam model secara bersama seperti pada tabel berikut:

Tabel 4. Seleksi Tahap Pertama Analisis Multivariat

\begin{tabular}{llll}
\hline Variabel & $\begin{array}{l}\text { Exp } \\
\text { (B) }\end{array}$ & $\begin{array}{l}\text { P } \\
\text { value }\end{array}$ & $\begin{array}{l}\text { OR (95 } \\
\text { \% C })\end{array}$ \\
\hline Pemberian ASI & 0.227 & 0.022 & $0.063-$ \\
& & & 0.811 \\
Pola asuh gizi & 3.661 & 0.074 & $\begin{array}{l}0.883- \\
15.185\end{array}$ \\
& & & $0.841-$ \\
Riwayat Penyakit & 2.929 & 0.091 & 10.200 \\
Infeksi & & & $0.268-$ \\
Pemanfaatan & 1.205 & 0.808 & 5.423 \\
$\begin{array}{l}\text { Pelayanan } \\
\text { Posyandu }\end{array}$ & & & \\
\hline
\end{tabular}

Berdasarkan tabel 4 terlihat bahwa variable pemanfaatan pelayanan posyandu mempunyai $\mathrm{p}$ value tertinggi sehingga dikeluarkan pertama kali dari model. Setelah pemanfaatan pelayanan posyandu dikeluarkan, tidak ada variable yang perubahan nilai $O R$ lebih dari $10 \%$ sehingga variable asupan protein keluar selamanya dari model.

Permodelan tahap kedua dengan mengeluarkan variable riwayat penyakit infeksi mempunyai $p$ value tertinggi sehingga dikeluarkan dari model. Setelah variable riwayat penyakit infeksi dikeluarkan, tidak ada variable yang perubahan nilai OR lebih dari $10 \%$ sehingga variabel riwayat penyakit infeksi keluar selamanya dari model. Hasil akhir dari analisis multivariat dapat dilihat selengkapnya pada tabel di bawah ini.

Tabel 5. Permodelan terkhir Analisis Multivariat

\begin{tabular}{lllll}
\hline Variabel & $\operatorname{Exp}(\mathbf{B})$ & $\begin{array}{l}\text { P } \\
\text { value }\end{array}$ & $\begin{array}{l}\text { OR }(95 \\
\text { CI })\end{array}$ & \\
\hline Pemberian & 0.214 & 0.013 & 0.063 & - \\
ASI & & & 0.722 & \\
Pola asuh & 4.571 & 0.013 & 1.370 & - \\
gizi & & & 15.248 & \\
\hline
\end{tabular}

Dari hasil keseluruhan proses analisis yang telah dilakukan dapat disimpulkan bahwa dari 7 variabel yang diduga berhubungan dengan stunting pada balita (12-59 bulan), ternyata hanya ada 2 variabel yang berhubungan secara bermakna berhubungan dengan stunting yaitu pemberian asi dan pola asuh gizi. Dari kedua variabel tersebut, dengan melihat nilai OR dari setiap variable dapat disimpulkan bahwa variable yang paling dominan berhubungan dengan stunting pada balita (12-59 bulan) adalah variable pola asuh gizi karena memiliki nilai OR paling besar yaitu 4.571 .

\section{Pembahasan}

Kejadian stunting pada balita diukur dengan menggunakan klasifikasi status gizi berdasarkan indikator tinggi badan menurut umur (Eastwood, 2003).

1. Stunting mencerminkan kegagalan dalam mencapai pertumbuhan linier yang potensial sebagai akibat adanya status kesehatan atau status gizi. Pertumbuhan linier atau tinggi badan dipengaruhi oleh factor genetic, factor lingkungan, dan kondisi medis. Peerkembangan dari stunting mmerupakan proses bertahap yang bersifat kronis, termasuk gizi buruk dan penyakit infeksi, selama periode pertumbuhan linier. Hal ini sering dimulai pada rahim dan meluas melalui dua tahun pertama. Tanpa perubahan lingkungan, stunting dapat menyebabkan penurunan pertumbuhan permanen. Dengan demikian, anak-anak yang mengalami stunting pada awal kehidupan seringkali lebih pendek pada masa kanak-kanak dan dewasa dibanding rekannya yang punya pertumbuhan awal yang memadai (Devi, 2010). 
Prevalensi stunting di Sumatera sebesar $37.5 \%$ lebh tinggi dari prevalensi stunting nasional hasil Riskesdas 2010 sebesar $35.6 \%$. Bila bandingkan dengan batas "non public health problem" menurut WHO, angka ini masih diatas ambang batas (cut off) yang telah disepakati secara universal. Apabila masalah stunting di atas $20 \%$ maka merupakan masalah kesehatan masyarakat (Eastwood, 2003).

Tingginya prevalensi stunting mengidentifikasikan bahwa pertumbuhan pada anak terkait dengan factor jangka panjang, termasuk tidak cukupnya asupan makanan, infeksi, tidak menyusui selama periode yang berkelanjutan, dan rendahnya status sosial ekonomi rumah tangga. Ini cukup terbukti dalam penelitian yang dilakukan oleh sayed et al (2001) tingkat sosial ekonomi tinggi dan status lingkungan yang baik ditemukan menjadi protektif terhadap stunting.

Eastwood (2003) menyatakan bahwa pola pertumbuhan ini ditandai dengan berkembangnya bayi, dan dilanjutkan dengan pertumbuhan selama remaja. Asupan makanan yang tidak memadai dalam 2 tahun pertama bertanggung jawab pada terjadinya stunting. Kurangnya proses menyusui, menyapih dan praktik pemberian makanan, infeksi dan diare juga berkontribusi. Martorell, Kettel Khan \& Schroeder (1994) menyatakan kegagalan pertumbuhan pada saat awal kehidupan akan menyebabkan tinggi badan pada saat dewasa kurang kecuali ada kompensasi pertumbuhan (catch-up growth) di masa anak-anak (Devi, 2010).

Untuk mengatasi permasalahan gizi pada anak seperti stunting pada balita sudah banyak kebijakan dan program yang dicanangkan olah pemerintah seperti, posyandu, DDTK (Deteksi Dini Tumbuh Kembang) pada balita dan anak, tetapi kedua program ini tidak dapat mengatasi permasalahan gizi pada balita mukin hal ini disebabkan karena tidak adanya evaluasi dan intervensi terhadap kedua kegiatan ini. Pada tahun 2012 pemerintah telah menyusun kerangka kebijakan terbaru yaitu kebijakan gerakan sadar gizi dalam rangka seribu hari pertama kehidupan yang bertujuan untuk mengatasi masalah anak stunting di Indonesia yang semakin memprihatinkan. Dimana kebijakan ini tidak dapat dilaksanakan oleh instansi kesehatan saja tetapi memerlukan kerja sama lintas sektoral dimana kebijakan ini memiliki dua program yaitu program sensitif diluar sektor kesehatan.

ASI ekslusif adalah memberikan hanya ASI saja bagi bayi sejak lahir sampai usia 6 bulan. Selama 6 bulan pertamapemberian ASI eksklusif, bayi tidak diberikan makanan dan minuman lain (Eastwood, 2003).

Hasil penelitian menunjukan bahwa proporsi kejadian stunting lebih banyak ditemukan pada responden diberikan ASI secara Ekslusif (63.6\%) lebih rendah dibandingkan dengan balita yang tidak mendapatkan ASI. Berdasarkkan hasil uji statistik dapat disimpulkan bahwa ada hubungan yang bermakna antara pemberian ASI dengan Kejadian Stunting. Balita yang tidak mendapatan ASI secara Eksklusif memiliki resiko 0,26 kali menderita stunting.

Balita yang tidak menyusui secara eksklusif hanya $32.0 \%$ yang menderita stunting hal ini mukin disebabkan karena balita yang tidak menyusui secara eksklusif $48.0 \%$ diberikan susu formula sebagai penambah ASI, dan $24.0 \%$ diberikan susu formula dan biskuit.

Penelitian Wiyogowati (2012) yang menyatakan bahwa anak yang stunting lebih tinggi pada ibu yang menyusui secara eksklusif. Berbeda dengan penelitian Hien dan Kam (2008)yang menyatakan risiko menjadi stunting 3.7 kali lebih tinggi pada balita yang tidak diberi ASI eksklusif dibandingkan dengan balita dengan ASI eksklusif (Anugraheni, 2012).

ASI adalah makanan bayi yang paling sempurna. Dari segi gizi, antibodi dan psikososial. ASI mempunyai peran penting terhadap pertumbuhan dan perkembangan anak. Menurut Anderson \& Remley, 1999 hasil metaanalisis menunjukkan bahwa anak-anak yang diberi ASI secara signifikan mempunyai fungsi kognitif lebih tinggi dibandingkan anakanak yang diberi susu formula dan perbedaan ini stabil sepanjang pertambahan usia. Ditemukan juga bahwa lamanya pemberian ASI berhubungan dengan pertumbuhan panjang badan terutama pada anak usia di bawah tiga tahun (Marquis, 1997; Simondon, et al, 2001; Ntab et al, 2005) dan ponderal indeks bayi $0 \square 6$ bulan (Anisa, 2012).

Kurangnya pengetahuan ibu tentang pentingnya ASI, juga maraknya promosi susu formula yang diwaktu yang lalu, menurut UNICEF, "out of control", merupakan hambatan yang menyebabkan tidak efektifnya promosi ASI Eksklusif. Dengan dikeluarkannya 
PP no 33 tahun 2012 tentang ASI sebagai peraturan pelaksanaan Undang-Undang no 23 Tahun 2009 tentang Kesehatan yang diharapkan dapat dilakukan tindakan hukum yang lebih tegas bagi penghambat pelaksanaan ASI Ekslusif. Kebijakan dan sasaran yang diharapkan pada program Gerakan 1000 HPK ini yaitu mengoptimalkan pelaksanaan UU Kesehatan 2009 yang terdapat sanksi tegas pada siapa yang dengan sengaja menhalangi program pemberian ASI Eksklusif (Pasal 200) dan sangsi pidana berat bagi korporasi (Pasal 2001) serta pelaksanaan PP no 33 tahun 2012 tentang ASI, sehingga jumlah bayi yang mendapat ASI-Eksklusif mencapai 80 persen (Soetjiningsih, 2000).

Engle (1997), pola asuh adalah kemampuan keluarga dan masyarakat untuk menyediakan waktu, perhatian dan dukungan dalam memenuhi kebutuhan fisik, mental dan sosial dari anak yang sedang tumbuh dan anggota keluarga lainnya. Pola asuh responden meliputi perhatian/dukungan ibu terhadap anak dalam pemberian makanan, rangsangan psikososial (Pola asuh diri) dan praktek kesehatan anak. Hasil penelitian menunjukan bahwa proporsi kejadian stunting lebih banyak ditemukan pada responden yang mendapatkan pola asuh yang kurang baik (66.7\%) lebih tinggi dibandingakan dengan responden yang mendapatkan pola asuh yang baik (35.5\%). Terdapat hubungan yang signifikan antara pola asuh gizi dengan Kejadian Stunting. Balita dengan pola asuh gizi yang kurang baik memiliki risiko menjadi Stunting 3.6 kali dibandingkan dengan balita yang memiliki pola asuh yang baik.

Salah satu faktor yang berperan penting dalam status gizi balita adalah pola asuh (Mustapa, Sirajuddin, Salam, 2013). Masalah gizi di pengaruhi oleh banyak faktor yang saling mempengaruhi secara kompleks. Salah satu yang mempengaruhinya yaitu ibu, keadaan gizi di pengaruhi oleh kemampuan ibu menyediakan pangan yang cukup untuk anak serta pola asuh yang di pengaruhi oleh faktor pendapatan keluarga, pendidikan, perilaku dan jumlah saudara. Hal tersebut didukung dengan hasil dari Husin (2008) dengan 82 responden yang menunjukan bahwa terdapat hubungan antara pola asuh dengan staus gizi balita umur 24-59 bulan.

Pola asuh gizi ibu baik jika didukungan dengan pengatahuan ibu tentang gizi juga baik, berdasarkan informasi yang didaptkan dari responden, dimana mereka tidak mengetahui bagaimana caramengatasi anak yang tidak mau makan dan maunya hanya jajan saja (junkfood) untuk itu dengan adanya kebijakan baru pemerintah yaitu gerakan 1000 HPK diharapkan pendidikan Gizi Masyarakat atau dalam bahasa operasionalnya disebut KIE (Komunikasi, Informasi dan Edukasi) Gizi. Bagi masyarakat umum, Pendidikan Gizi untuk memberikan pengetahuan, menumbuhkan sikap dan menciptakan perilaku hidup sehat dengan Gizi Seimbang. Dalam gizi seimbang tidak hanya mendidik soal makanan dan keseimbangan komposisi zat gizi dan kebutuhan tubuh akan zat gizi (karbohidrat, protein, lemak, vitamin dan mineral, dan air), tetapi juga kesimbangan dengan pola hidup bersih untuk mencegah kontaminasi makanan dan infeksi sehingga dapat memahami bagaimana pola asuh gizi yang baik itu.

Kebijakan yang diharapkan dari pemerintah untuk menyamakan konsep dan pola pikir tentang masalah gizi (apa, mengapa, dan bagaimana) diantara para pelaku program gizi, kegiatan Pendidikan Gizi harus menjadi dasar perbaikan gizi masyarakat umumnya, dan secara khusus untuk tujuan 1000 HPK. Untuk itu diperlukan tersedianya data dasar tentang pengetahuan, sikap dan perilaku tentang gizi yang benar diberbagai kalangan masyarakat. Diperlukan adanya suatu lembaga KIE yang mengelola KIE 1000 HPK. Disediakan anggaran yang cukup untuk kegiatan pendidikan gizi masyarakat.

Penghasilan yang cukup ketika diimbangi dengan pengetahuan gizi yang memadai, dan pemanfaatan pangan yang baik,kebutuhan gizinya akan terpenuhi secara kualitas maupun kuantitas. Keluarga yang tingkat pendapatannya meningkat tidak selalu membelanjakan untuk kebutuhan gizi tapi sebaliknya dibelanjakan untuk barang yang dapat meningkatkan status sosial. Banyak terdapat anak dengan status gizi kurang pada ayah dan ibu yang secara ekonomi seharusnya dapat mencukupi kebutuhan makanan yang bergizi.

Hasil penelitian proporsi stunting lebih tinggi di dapatkan pada keluarga yang pendapatannya cuku baik dibandingkan dengan keluarga yang berpendapatan kurang baik (dibawah standar upah minimum Kota Padang). Walaupun secara proporsi terdapat ada nya perbedan, tetapi secara statistik tidak terdapat 
hubungan yang signifikan antara pendapatan keluarga dengan Kejadian Stunting.

Penelitian Damanik, ekayanti, \& hariyadi (2010) Status ekonomi keluarga dipandang memiliki dampak yang signifikan terhadap probabilitas seorang anak menjadi pendek atau kurus. Dimana WHO merekomendasikan status gizi stunting sebagai alat ukur atas tingkat sosial-ekonomi yang rendah dan sebagai salah satu indicator untuk memantau ekuitas dalam kesehatan. Status ekonomi secara tidak langsung dapat mempengaruhi status gizi anak, sebagai contoh, keluarga dengan status ekonomi baik bias mendapatkan pelayanan umum yang lebih baik, maka akan berdampak positif terhadap status gizi anak (Anisa, 2012).

Suhardjo (2003) mengemukakan bahwa pendidikan ibu merupakan faktor yang sangat penting. Tinggi rendahnya tingkat pendidikan ibu erat kaitannya dengan tingkat pengetahuan terhadap perawatan kesehatan, proses kehamilan dan pasca persalinan, serta kesadaran terhadap kesehatan dan gizi anakanak dan keluarganya. Tingkat pendidikan turut pula menentukan mudah tidaknya seseorang lebih tanggap terhadap adanya masalah gizi didalam keluarga dan bisa mengambil tindakan secepatnya (Eastwood, 2003).

Hasil analisis menunjukkan proporsi kejadian stunting pada balita lebih banyak pada pendidikan ibu tinggi dibandingkan pada pendidikan ibu rendah secara statistik tidak terdapat hubungan yang signifikan antara tingkat pendidikan ibu dengan kejadian stunting.

Penelitian ini walaupun ibu berpendidikan tinggi kalau tidak mengetahui tentang bagaimana pengertian gizi, permasalahannya, penyebab dari masalah gizi pada balita, masalah stunting tidak dapat diatasi, untuk itu diperlukannya kebijakan pemerintah tentang pendidikan gizi pada masyarakat atau yang disebut dengan KIE gizi. Dimana program ini bertujuan untuk memberikan pengetahuan, menumbuhkan sikap dan menciptakan perilaku hidup sehat dengan Gizi Seimbang. Dalam gizi seimbang tidak hanya mendidik soal makanan dan keseimbangan komposisi zat gizi dan kebutuhan tubuh akan zat gizi (karbohidrat, protein, lemak, vitamin dan mineral, dan air).

Hasil analisis menunjukkan bahwa proporsi kejadian stunting pada balita lebih banyak ditemukan pada jumlah anggota keluarga yang $\geq 5$ orang dibandingkan balita dengan jumlah anggota keluarga $<5$ orang. Walaupun terdapat perbedaan proporsi, hasil analisi menunjukan bahwa tidak ada hubungan yang bermakna antara jumlah keluarga dengan kejadian Stunting.

Penelitian Ramli et al (2009) dan Fitri (2012) yang menyatakan bahwa tidak ada hubungan secara signifikan dengan stunting pada balita. Berdasarkan penelitian Astari, Nasoetion \& Dwiriani (2006) yang dilakukan di kabupaten Bogor, rata-rata besar keluarga pada kelompok anak stunting dan normal dapat dikatakan tidak berbeda. Sebagian Besar (>50\%) besar keluarga pada kedua kelompok tersebut secara statistic tidak terdapat peerbedaaan yang nyata besar keluarga antara kelompok anak stunting dan kelompok anak normal ${ }^{(6)}$.

Ada hubungan erat antara jumlah anak, jarak kehamilan dan kelahiran, ASI-Eksklusif, dengan prevalensi anak pendek dan anak kurus karena kekurangan gizi (Rae Golloway, 2011, Integrating Family Planning and Councelling on Nutrition for Children 6-23 months, in FPMNCH-Nutrition Integration Technical Consultation March 30, 2011, USAID Washington) (Soetjiningsih, 2008). Tetapi pada penelitian ini jumlah keluarga tidak memiliki hubugan yang bermakna dengan kejadian stunting. dan kebijakan pembangunan di bidang keluarga berencana dulunya dapat mengatasi masalah jumlah keluarga.

Keterpaduan Gizi-KB di Indonesia terputus sejak akhir 1990, sejalan dengan perubahan kebijakan pembangunan di bidang keluarga berencana dan program perbaikan gizi selama kurun waktu 15 tahun terakhir. Adanya pengakuan dunia bahwa KB Indonesia berhasil menurunkan angka kelahiran dari 5,6 persen tahun 1970 ke 2,1 persen tahun 2011, berarti program KB sudah dapat dikatakan berpotensi menjadi program yang sensitif terhadap 1000 HPK di Indonesia.

Penyakit infeksi merupakan salah satu faktor penyebab langsung status gizi balita disamping konsumsi makanan. Hasil penelitian menunjukan bahwa proporsi balita yang memiliki riwayat penyakit infeksi $62.9 \%$ menderita stunting lebih tinggi dibandingakan dengan responden yang tidak memiliki riwayat penyakit $(30.4 \%)$. Terdapat hubungan yang signifikan antara riwayat penyakit infeksi dengan kejadian stunting. Balita yang memiliki riwayat penyakit infeksi dalam 6 bulan terakhir 
memiliki resiko menjadi stunting sebesar 3.8 kali dibandingkan dengan balita yang tidak memiliki riwayat penyakit infeksi dalam 6 bulan terakhir.

Penelitian Masithah, soekirman, \& Martianto (200\%) (Anisa, 2012), dimana anak yang menderita penyakit infeksi memiliki hubungan yang positif dengan stunting. Penelitian lain juga menyatakan bahwa penyakit infeksi menjadi faktor kejadian stunting pada anak dibawah 5 tahun (Soetjiningsih, 2000). Penyakit infeksi menunjukan hubungan yang signifikan dengan terhadap stunting (Anisa, 2012).

Penelitian proporsi menderita stunting lebih tinggi terdapat pada balita yang tidak memanfaatkan pelayanan posyandu $(60.9 \%)$ dibandingkan dengan responden yang memanfaatkan pelayanan posyandu (42.9\%). Berdasarkkan hasil uji statistik tidak terdapat hubungan yang signifikan antara pemanfaatan pelayanan posyandu dengan kejadian stunting

Pelayanan kesehatan adalah akses atau keterjangkauan anak dan keluarga terhadap upaya pencegahan penyakit dan pemeliharan kesehatan seperti imunisasi. Kurangnya pengetahuan merupakan kendala masyarakat dan keluarga memanfaatkan secara baik pelayanan kesehatan yang tersedia yang dapat berdampak pada status gizi anak (Soetjiningsih, 2012).

Penelitian Schroder (2001) dalam Fitri (2012) yang menyatakan bahwa kekurangan gizi dipengaruhi oleh konsumsi makanan yang kurang dan adanya penyakit infeksi dan penyebab yang mendasarnya adalah makanan, pola asuh dan pelayanan kesehatan. Soetjiningsih (2012) mengemukakan bahwa kesehatan anak harus mendapat perhatian dari para orang tua yaitu dengan segera membawa anaknya yang sakit ketempat pelayanan kesehatan yang terdekat. Masa balita sangat rentan terhadap penyakit seperti : flu, diare atau penyakit infeksi lainnya. Salah satu faktor yang mempermudah anak balita terserang penyakit adalah keadaan lingkungan.

Kontak dengan pelayanan kesehatan akan membantu memperbaiki masalah gizi baru, sehingga status imunisasi juga diharapkan akan memberikan efek postif terhadap status gizi jangka panjang (Anisa, 2012).

Hal ini sudah diatur dalan UUD 1945 pasal 28 yang menyatakan bahwa setiap anak itu berhak atas kelangsungan hidup, tumbuh dan berkembang dan setiap orang berhak memperoleh pelayanan kesehatan.

Faktor dominan yang berhubungan dengan stunting diperoleh berdasarkan analisis multivariat. Analisis multivariat yang digunakan adalah analisis regresi logistic ganda karena variable dependen bersifat kategorik. Dari proses analisis multivariat hanya ada 2 variabel yang berhubungan secara bermakna berhubungan dengan stunting yaitu pemberian asi dan pola asuh gizi.

Dari kedua variabel tersebut, dengan melihat nilai OR dari setiap variabel dapat disimpulkan bahwa variabel yang paling dominan berhubungan dengan stunting pada balita (12-59 bulan) adalah variable pola asuh gizi karena memiliki nilai OR paling besar yaitu 4.571 artinya balita yang mempunyai pola asuh kurang baik berpeluang menjadi stunting sebesar 4.5 kali dibandingkan dengan balita yang mendapatkan pola asuh yang baik.

Permasalahan stunting merupakan masalah yang sangat kompleks, karena banyak hal yang bisa menyebabkan permasalahan ini, untuk itu dilakukan analisis multivariat. Dari hasil analisis ini didapatkan bahwa factor penyebab stunting yang paling dominan adalah pola asuh gizi pada balita. Dimana pola asuh salah satu faktor yang berperan penting dalam status gizi balita. Masalah gizi di pengaruhi oleh banyak faktor yang saling mempengaruhi secara kompleks. Salah satu yang mempengaruhinya yaitu ibu, keadaan gizi di pengaruhi oleh kemampuan ibu menyediakan pangan yang cukup untuk anak serta pola asuh yang dipengaruhi oleh faktor pendapatan keluarga, pendidikan, perilaku dan jumlah saudara.

Pola asuh gizi ibu baik jika didukungan dengan pengetahuan ibu tentang gizi juga baik, berdasarkan informasi yang didapatkan dari responden, dimana mereka tidak mengetahui bagaimana cara mengatasi anak yang tidak mau makan dan maunya hanya jajan saja (junkfood) untuk itu dengan adanya kebijakan baru pemerintah yaitu gerakan 1000 HPK diharapkan pendidikan Gizi Masyarakat atau dalam bahasa operasionalnya disebut KIE (Komunikasi, Informasi dan Edukasi) Gizi. Bagi masyarakat umum, Pendidikan Gizi untuk memberikan pengetahuan, menumbuhkan sikap dan menciptakan perilaku hidup sehat dengan Gizi Seimbang. Dalam gizi seimbang tidak hanya mendidik soal makanan dan keseimbangan komposisi zat gizi dan 
kebutuhan tubuh akan zat gizi (karbohidrat, protein, lemak, vitamin dan mineral, dan air), tetapi juga kesimbangan dengan pola hidup bersih untuk mencegah kontaminasi makanan dan infeksi sehingga dapat memahami bagaimana pola asuh gizi yang baik itu.

Sehingga dapat disimpulkan bahwa jika pola asuh gizi ibu baik maka dapat mengatasi masalah variabel lainnya. Diharapkan dengan adanya kebijakan baru pemerintah yaitu 1000 HPK dengan program Spesifik dan sensitifnya dapat mengatasi semua varibael yang berhubungan dengan permasalahan gizi pada balita terutama stunting pada balita.

\section{Kesimpulan}

1. Balita yang tidak diberikan ASI secara Ekslusif 27.6\% menderita stunting

2. Balita yang mendapatkan pola asuh yang kurang baik $62.1 \%$ menderita stunting

3. Balita yang pendapatan keluarganya yang kurang baik 27,6\% menderita stunting

4. Tingkat pendidikan ibu yang rendah $10,3 \%$ balitanya menderita stunting

5. Balita yang memiliki jumlah keluarga yang lebih dari lima orang 37.9\% menderita stunting

6. Balita yang memiliki riwayat penyakit infeksi 75,9\% menderita stunting

7. Balita yang tidak memanfaatkan pelayanan posyandu $48,3 \%$ menderita stunting

8. Ada hubungan yang bermakna antara pemberian ASI dengan Kejadian Stunting dengan nilai $\mathrm{OR}=0,269$

9. Ada hubungan yang bermakna antara pola asuh gizi dengan Kejadian Stunting dengan nilai $\mathrm{OR}=3.63$

10. Tidak ada hubungan yang bermakna antara pendapatan keluarga dengan Kejadian Stunting

11. Tidak ada hubungan yang bermakna antara tingkat pendidikan ibu dengan Kejadian Stunting

12. Tidak ada hubungan yang bermakna antara jumlah keluarga dengan Kejadian Stunting.

13. Ada hubungan yang bermakna antara riwayat penyakit infeksi dengan kejadian stunting dengan nilai OR 3.868

14. Tidak ada hubungan yang bermakna antara pemanfaatan pelayanan posyandu dengan kejadian stunting

\section{Saran}

1. Diharapkan kepada petugas kesehatan dapat melaksanakan dengan baik kebijakan baru pemerintah yaitu 1000 HPK

2. Diharapkan kepada petugas kesehatan dan masyarakat mengoptimalkan pelaksanaan UU Kesehatan 2009 yang terdapat sanksi tegas pada siapa yang dengan sengaja menhalangi program pemberian ASI Eksklusif (Pasal 200) dan sangsi pidana berat bagi korporasi (Pasal 2001) serta pelaksanaan PP no 33 tahun 2012 tentang ASI.

3. Diharapkan Program KB tetap dilanjutkan karena banyak ibu hamil yang tidak mampu dapat tertolong dan tingkat partisipasinya cukup tinggi.

4. Diharapkan kepada petugas kesehatan terutama kader posyandu dapat meningkatkan monitoring pertumbuhan balita di posyandu sehingga dapat mengurangi risiko terjadinya stunting pada balita.

5. Diharapkan peranan petugas posyandu lebih ditingkatkan lagi dalam hal pelaksanaan penimbangan, pengukuran tinggi badan dan imunisasi serta juga memberikan edukasi kepada ibu balita mengenai pentingnya perhatihan terhadap pertumbuhan balita.

6. Diharapkan dibentuknya pusat pengembangan KIE Gizi yang dikelola oleh tenaga profesional di bidang gizi, kesehatan masyarakat, IT, dan bidangbidang lain yang terkait.

7. Diharapkan kepada petugas kesehatan dapat melaksanakan dengan baik kebijakan baru pemerintah yaitu 1000 HPK.

8. Diharapkan kepada petugas kesehatan dan masyarakat mengoptimalkan pelaksanaan UU Kesehatan 2009 yang terdapat sanksi tegas pada siapa yang dengan sengaja menhalangi program pemberian ASI Eksklusif (Pasal 200) dan sangsi pidana berat bagi korporasi (Pasal 2001) serta pelaksanaan PP no 33 tahun 2012 tentang ASI.

9. Diharapkan Program KB tetap dilanjutkan karena banyak ibu hamil yang tidak mampu dapat tertolong dan tingkat partisipasinya cukup tinggi.

10. Diharapkan kepada petugas kesehatan terutama kader posyandu dapat 
meningkatkan monitoring pertumbuhan balita di posyandu sehingga dapat

\section{Daftar Pustaka}

Allen, L.H. 2002 Nutritional Influences on Linier Growth (On-Line). Available on: www.unu.edu/Unpress/food2/uid06eu.htm

Astari LD, Nasoetion A, Dwiriani CM, 2005. Hubungan Karakteristik Keluarga, Pola Pengasuhan dan Kejadian Stunting Anak Usia 6-12 Bulan. Media Gizi dan Keluarga.

Anugraheni, H. S.; 2012. Faktor Risiko Kejadian Stuntingpada Anak Usia 12-36 Bulan di Kecamatan Pati, Kabupaten Pati. Program Studi Ilmu Gizi Fakultas Kedokteran Universitas Diponegoro. Semarang.

Anisa, P. 2012. Faktor yang Berhubungan dengan Stunting pada Balita Usia 25 - 60 bulan di Kelurahan Depok. Universitas Indonesia. Skripsi

Devi, M. 2010. Analisis Faktor-Faktor Yang Berpengaruh Terhadap Status Gizi Balita Di Pedesaan. Vol. 33, No.2, Teknologi dan Kejuruan, (online), diakses 17 Juni 2013.

Eastwood, M. 2003. Principle of Human Second Edition. Blackwell Science Ltd, a Blackwell Publishing Company.

Fitri. 2012. Berat Lahir sebagai Faktor Dominan Terjadinya Stunting pada Balita (12 - 59 Bulan) di Sumatera. Universitas Indonesia

Kemenkes RI, 2010. StandarAntropometri Penilaian Status Gizi Anak. Direktorat Bina Gizi mengurangi risiko terjadinya stunting pada balita.

Kemenkes RI, 2012. Kerangka Kebijakan Gerakan Sadar Gizi Dalam Rangka Seribu Hari Pertama Kehidupan (1000 Hpk). Balitbang

Kemenkes RI, 2013. Riset Kesehatan Dasar. Balitbang

Purwandini K, Kartasurya M I. 2013. Pengaruh Pemberian Mikronutrient Sprinkle Terhadap Perkembangan Motorik Anak Stunting Usia 12-36 Bulan. Journal of Nutrition College; Volume 2 Nomor 1 Halaman 147-163.

Soetjiningsih, 1998. Tumbuh Kembang Anak. Jakarta :Penerbit Buku Kedokteran EGC.

Soetjiningsih, 2000. Tumbuh Kembang Anak. Jakarta :Penerbit Buku Kedokteran EGC.

Soetjiningsih, 2012. Tumbuh Kembang Anak. Jakarta : Penerbit Buku Kedokteran EGC

Suhardjo. 2003. Perencanaan Pangan dan Gizi. Jakarta : Rineka Cipta

Taguri, A. E., et al. 2008 "Risk Faktor Stunting Among Under Five in Libya", Public Health Nutrition, 12 (8). Diakses dari www.ncbi.nlm.gov

Thaha R. 1996. Gizi Kesehatan Ibu dan Anak, Kerangka Konsep dan Metode Pengukuran. Indikator. Vol.3, no.1

Wiyogowati, C. 2012. Kejadian Stunting pada Anak Berumur dibawah Lima Tahun (0-59 Bulan) di Propinsi Papua Barat Tahun 2010. Universitas Indonesia. 